\title{
Analysis of Factors Affecting Human Development Index in the City of Binjai
}

\author{
Elisabet Novita Barus ${ }^{1}$, HB. Tarmizi ${ }^{2}$, Rahmanta $^{3}$ \\ ${ }^{1}$ Postgraduate Students, Faculty of Economics and Business, Department of Economics, Universitas Sumatera \\ Utara, Indonesia \\ ${ }^{2,3}$ Postgraduate Lecturer, Faculty of Economics and Business, Department of Economics, Universitas Sumatera \\ Utara, Indonesia
}

Corresponding Author: Elisabet Novita Barus

\begin{abstract}
This study aims to analyze the Factors That Affect Human Development Index in the City of Binjai with variable observations shopping area in the field of health, education, population, and income per capita. This research is causality by performing multiple regression analysis (Multiple Regression Analysis). The Data used is the data of the year 2005 up to 2019 are presented per semester ( $\mathrm{n}=30$ samples). The results of the study concluded that the shopping area in the field of health, expenditure on education, expenditure in the field of population, and per capita income is able to influence the human development index in the local government of the City of Binjai. Based on the value of the coefficient of determination ( $r$ square) of all the variables, it was concluded that per capita income is a variable dominant that affect the human development index in the local government of the City of Binjai.
\end{abstract}

Keywords: The Human Development Index, A Shopping Area In The Field Of Health, Expenditure On Education, Expenditure In The Field Of Population, And Per Capita Income

\section{INTRODUCTION}

In carrying out the functions of community service, improving the quality of community service done by the government is one measure of the success of governance itself. Improved quality of service in today's society is becoming a crucial issue faced by the entire government at local and central government. On the other hand, there are greater demands of the society in the era of regional autonomy that the government can improve the quality of excellent service. In fact, many still found problems related to service to the community.

In the era of regional autonomy is currently closely associated with democratic principles as the foundation of the approach from the perspective of the public as users of the service in assessing the performance of the service should be an important concern to determine to what extent the services provided meet the expectations, satisfaction and needs of the public and other local as its constituents. This is in line with the principle of representative democracy, where the representation of local public not only on their representatives in Parliament, but also to represent the needs and interests of those who manifest in policies and development programs provided by the Local Government.

To see the successful development of a region, can be measured by several parameters, and the most popular today is the Human Development Index or the Human Development Index (Maulana and Bowo 2013). UNDP construct a composite index that the Human Development Index is based on three indicators: life expectancy at birth (life expectancy at birth), the literacy rate of the adult population (adult literacy rate) and the average length of the school (the mean years of schooling), and 
purchasing power (purchasing power parity).

The Human Development index is the human development index which is used to measure the achievement of the result of the construction of an area or region has 3 basic dimensions of development, namely education, health, and incomes. (1) Health (life expectancy), (2) Level of education (knowledge) and (3) Income (standard of living worth it). Indicator life expectancy measure health indicators literacy rate of the adult population and the average length of the school measure of education and the last indicator of the purchasing power of measuring the standard of living (Bhakti et al., 2014; Ginting et al., 2008).

The Human Development Index is a measure to see the performance impact of the construction of a region that has a dimension that is very widespread, due to the shows quality of the inhabitants of a region in terms of life expectancy, education and standard of living worthy of (Melliana and Zain, 2013). Human Development Index is a policy tool (Spangenberg, 2015) which is the result of a comprehensive overview of the various factors (Niu et al., 2013). Human Development Index is present as a measuring tool which is able to describe the level of welfare thoroughly because it can describe the factors of economic and non-economic (Aji et al., 2014).

The city of Binjai as one of the cities in the Province of North Sumatra which is only $\pm 22 \mathrm{Km}$ from the city of Medan and is a satellite town of the City of Medan. The city of Binjai area that has 9.023,62 $\mathrm{Ha}( \pm$ 90,23 Km2) consists of 5 (five) Districts and 37 (thirty-seven) as well as the Village has a population of as much as 273.892 (Binjai In Numbers, 2019), composed of various ethnic groups of the compound. The amount of the female population is large compared with the number of the male population, indicated by the ratio of the sexes is equal 99,66 a mean of about 1,000 female population there are the male population as much as 996 soul. Population density in the
City of Binjai tahun 20183.035 people $/ \mathrm{km} 2$ with the average number of residents per household of 4 people. Population density in the 5 districts are quite varied with the density of population is highest in Binjai City of $6.869 / \mathrm{km} 2$ and the lowest in District Binjai South of the 1876 jiwa/ $/ \mathrm{km} 2$. Meanwhile, the number of households by 62.894 (Binjai In Numbers, 2019).

Binjai city as a city of services, industry, trade and settlements have attempted to spur the growth pace of development that supports economic growth. Binjai is also an oil-producing regions of the earth and the gas is characterized by the exploration of petroleum and natural gas in the area of Tandam Hilir, District Binjai Utara. In general, there are four sectors that are quite dominant in the formation of the total GDP of the City of Binjai, namely the manufacturing Sector, Trade, Hotels and Restaurants, the Financial Sector, Rental and Services of the Company and the Services Sector. The plantation of course the concern is the plantation rambutan reached 425 ha with a production capacity of 2,400 tons per year.

The results of the National Socio Economic Survey 2018, the poverty line in the City of Binjai in the amount of Rp. 380.792 with the number of poor people as much as 16.070 people. While the gini ratio for the City of Binjai in 2018 amounted to 0,308 (Binjai In Numbers, 2019). Based on data from the year 2018 can be seen the ratio of the number of poor population to the total population in the City of Binjai is equal to 1-to-17 (16.070 the population is poor compared to 273.892 total occupation of the City of Binjai.)

Year 2020 is of political expiry of the term of office of the mayor which is now being served. During some period of the previous mayor, research needs to be done for the satisfaction of the community on the Performance of Local Government the City of Binjai in organizing public services related to the improvement of Human Development Index in Binjai City 
which is viewed from the side of service in the field of health, education, and the economic side of the community.

In the field of health, health expenditure government area is the allocation of expenditure used in order to fund the implementation of government affairs under the authority of the provincial or district/city in the field of health. Based on Law Number 36 year 2009 article 171 paragraph (2) states that large health budget the government allocated a minimum of 10 percent of the Budget outside of salary. Health is the most important thing in the life of the community, with a healthy person will be able to perform the actions of the social and economic to increase the life. In The Law No. 36 Year 2009 on Health Article 1 of that sound health is a healthy state, both physical, mental, spiritual and social that allows everyone to live socially and economically productive. Based on what mentioned in article 1 of Law No. 36 Year 2009 on the above indicates that aspects of the health of be the main to achieve the perfection of life. Ironically in Indonesia has the quality of public health during this relatively low. It is based on the results of the survey AIA Group that puts indonesia at the lowest position of the 15 countries in the Asia-Pacific region, Indonesia get a score of 55 out of a perfect score of 100. (The results of the Survey AIA Group 2013).

In the field of education, shopping area in the field of education is a type of shopping precinct that is used in order to fund the implementation of government affairs under the authority of the provincial or district/city in the field of education. In Law Number 20 Year 2003 about the allocation of funds for education mentioned that education funding in addition to the salary of teachers and the cost of education official is allocated at least $20 \%$ of the Budget Revenue and Expenditure (Budget) in the education sector and a minimum of $20 \%$ of the Regional Revenue and Expenditure Budget.
Based on Law No. 23 Year 2006, the Population Administration is a series of activities structuring and control in the issuance of documents and data through population registration of the population, civil registration and management of information as well as the utilization of the result to the public service and development.

Per capita income is the average income of a resident of a state (Untoro, 2010). Per capita income shows the income level of the people in a country. Variables used to calculate the income per capita is the gross national product and population. Indicator of the ability of the purchasing power of people against a number of commodities that are seen from the average magnitude of the expenditure per capita as the income approach, which represents the achievement of development for a decent life. According to Rakiman (2011) per Capita Income of a country is the measure of the progress of the country, if the per capita income of a country can be ascertained the mechanism of the economic society in the country has decreased, and vice versa, if per capita income of a country is high then it can be ascertained the economic mechanism of the community has increased, but the income is not only obtained/acquired from the mechanism economics course, many factors affect the decrease/ increase of income such as state of nature which could not be foreseen circumstances, the conditions of this nature can be changed at any time which can cause a natural disaster that will make the income of a country will decline. This applies to all countries in the world are no exception in the country of Indonesia.

\section{LITERATURE REVIEW \\ Human Development index}

The Human Development Index is a composite index to measure the achievement of the quality of human development to be able to live in higher quality, both from the aspect of health, education, and economic aspects. Human 
Development Index is also used to classify whether a country is a developed country, developing country or underdeveloped country and also to measure the impact of economic policy on quality of life (UNDP, 1996).

\section{Regional Revenue and Expenditure Budget}

Regional Revenue and Expenditure budget according to the definition issued by the Director general Perimbngan of Finance the Ministry of Finance of the Republic of Indonesia (2017) is the financial plan of the local government for one year stipulated by local regulations. The Budget can be used as a means of communication of local government to the community regarding the priority of the allocation made by the local government after coordination with the legislature, the regional Parliament.

\section{Shopping Area}

Shopping local is all the obligations of the regional yan recognized as a reduction of the value of its net assets in the period of the budget year concerned (UU 32/2004).

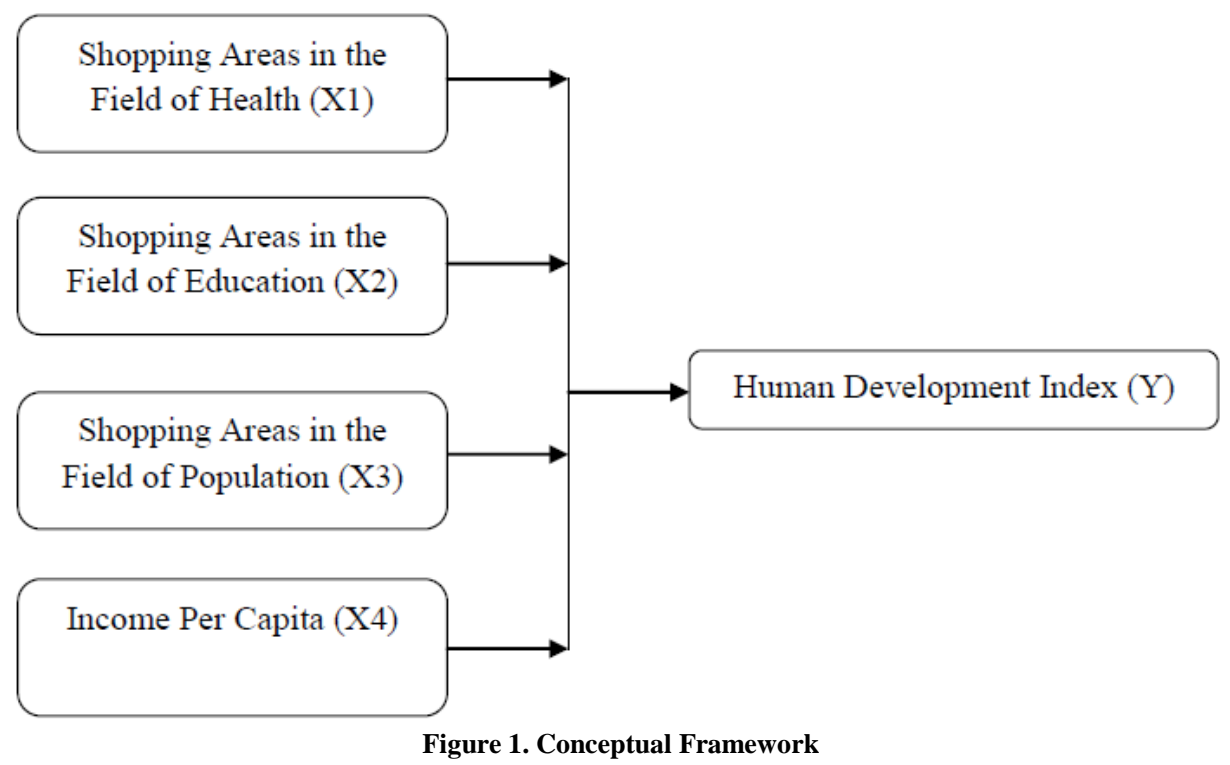

\section{Hypothesis}

This research will test the hypothesis, i.e. how large the influence of the Expenditure of Local Government in the Field of Health Expenditure of Local Government in the Field of Education, Expenditure of Local Government in the Field of Kependuduk and Per Capita Income of the cosmos, the Human Development Index.

\section{MATERIAL AND METHODS}

This research is causality. Research causality aims to investigate the possibility of a causal relationship of an event/phenomenon and seeks to provide empirical evidence and analyze the factors that affect Human Development Index in the City of Binjai.

Data used by the researcher is secondary data in the realization of the allocation of expenditure in the field of health, education, population, income per capita and the human development index in the City of Binjai with the retrieval of the data in the period 2005 up to 2019 are presented per semester ( $\mathrm{n}=30$ samples) is referred to as time series data.

Data collection methods used by the researcher are secondary data, namely the Realization of the Budget of the Government of the City of Binjai and data of Human Development Index in the City of Binjai. Source data were obtained from BPKPAD the City of Binjai and BPS City 
of Binjai (kotabinjai.bps.go.id). The research Data presented in the time series (free time).

\section{RESULTS AND DISCUSSION The Influence Of The Shopping District In The Field Of Health On The Human Development Index}

Based on the results of the multiple linear regression test obtained the value of the regression coefficient of $-2,415 \mathrm{E} 11$, with a significance level 0,018. The significance value smaller than 0.05 and the regression coefficient is positive, then the partial variable independent Shopping Areas in the Field of Health and a significant negative effect on the dependent variable Human Development Index. Thus the first hypothesis is accepted.

The results of this study in accordance with the research Heka (2017) in the research on the Effect of Government Spending for Health and Education On Human Development Index in the Province of North Sulawesi, which states that the Government Spending the Field of Health have a significant effect on Human Development Index in the Province of North Sulawesi.

Research Umihani (2004) on the Influence of Per Capita Income And Expenditure of the Government Social sector To the Human Development Indicators: a Case Study of District/City in Central Java Province, which concluded that the government Expenditure for education and health have a more powerful influence than income per capita. In the field of education, government spending for the program, college and school education program is more effective than school education program. For The Development of Gender Equality (IPG), the results estimated by using Ordinary Least Square method shows only government expenditure health in a positive and significant effect.

Based on the results of research Marhaeni (2011) for Analysis of the Effect of Spending On Education And Health Of the Government And the Household, as well
As Micro-Credit, Small, and Medium Against the Gender Development Index In the District/City In East Java Province, is known to influence government spending in education and health to the IPG is significant and the direction of the coefficient is positive, but the influence of government spending was the smallest compared with the household expenses and credit micro, small, and medium enterprises to the IPG.

The results of this study are not in line with the research Muliza (2017) which states that the variable of government expenditure in the health sector has no significant effect on the human development index in the Province of Aceh, this happens because the government of regency/city in the Province of Aceh is still more dominant allocate its spending on the type of spending that is not directly influence on the Human Development Index.

Table 1 The Number Of Medical Personnel And Paramedics On Duty At The Hospital Dr RM Djoelham The City Of Binjai

\begin{tabular}{|c|c|c|}
\hline \multirow[t]{2}{*}{ No } & Power Health & Total \\
\hline & \multicolumn{2}{|l|}{ I. Medical } \\
\hline 1. & General practitioners (PNS PTT ) & 22 \\
\hline 2. & Doctor Surgeon & 3 \\
\hline 3. & Internist & 6 \\
\hline 4. & Doctor Child & 6 \\
\hline 5. & Specialist Obstetrics and Gynecologi & 5 \\
\hline 6. & Specialist Clinical Pathology & 4 \\
\hline 7. & The ENT & 4 \\
\hline 8. & Ophthalmologist & 2 \\
\hline 9. & Expert Doctors Pulmonary & 1 \\
\hline 10. & Expert Doctors Anesthesi & 2 \\
\hline 11. & Doctor Neurologist & 2 \\
\hline 12. & Dermatologist And Sex & 1 \\
\hline 13. & Doctor Surgeon Orthopaedic & 1 \\
\hline 14. & The Expert Physicians Of The Soul & 1 \\
\hline 15. & Doctor Spes Radiology & 1 \\
\hline 16. & Doctor Spes Anatomic Pathology & 2 \\
\hline 17. & Doctor Spes Forensic & 2 \\
\hline 18. & Doctor S Heart & 2 \\
\hline 19. & Doctor Spes Neurosurgery & 0 \\
\hline \multirow[t]{2}{*}{20.} & Doctor Teeth (of CIVIL servants and PTT) & 13 \\
\hline & \multicolumn{2}{|l|}{ II. The Medical Nursing } \\
\hline 1. & S-2 Nursing & 3 \\
\hline 2. & S-1 Nursing & 67 \\
\hline 3. & Academy Of Nursing & 52 \\
\hline 4. & SPK / SPRA & 23 \\
\hline 5. & Midwives D4 & 8 \\
\hline 6. & Nurse Midwife D3 & 14 \\
\hline 7. & PKE & 0 \\
\hline 8. & PKC & 0 \\
\hline 9. & SPRG /AKG & 10 \\
\hline 10 & Midwives D1 & 0 \\
\hline \multicolumn{2}{|c|}{ Total } & 263 \\
\hline
\end{tabular}


In an effort to improve the quality of public health, the Government of the City of Binjai has built a variety of facilities and infrastructure that are scattered throughout the territory of the City of Binjai. When this has been established 9 hospital and 8 health centers coupled with 6 Clinic/Health Center. Meanwhile, when viewed from a fleet of health personnel available, there are approximately 312 doctor, 648 people nursing, 358 people skilled midwifery. When viewed in specific, there are about 96 people specialist, 165 general practitioners and 51 people the dentist.

Population problems are common problems faced by every country in the world. Although every country has a population problem, but the problem of population in each country can be different. Population problems that occur in Indonesia also this review helpful. Indonesia as a country has a population problem that is quite heavy and need to be immediately addressed. If the population problem can be overcome with good, then the problem of development and prosperity of the inhabitants of the next will also be able to be dealt with better. Population problem in general can be distinguished in two things in common, which is based on the quantity and quality of the population. To determine the data quality as well as quantity of the population, a country can do a variety of ways, such as by using census method, registration, and a survey of the population.

The Human Development index is an important indicator to measure the success in the effort to build the quality of human life (the community/population). Human Development Index explain how the resident can access the results of development in earned income, health, education, and so on.

From Table 1 it can be seen the number of Medical Personnel and paramedics on duty at the Hospital dr RM Djoelham the City of Binjai as much as 263 serving the people of the City of Binjai in the field of health services.

Table 2 The Number Of Medical Personnel And Paramedics On Duty In The Department Of Health Of The City Of Binjai

\begin{tabular}{|c|c|c|c|c|c|}
\hline No & Health Centers & General Physician & Dentist & Midwife & Nurse \\
\hline 1 & Health Centers Binjai Kota & 5 & 2 & 7 & 18 \\
\hline 2 & Health Centers Rambung & 6 & 3 & 11 & 9 \\
\hline 3 & Health Centers Kebun Lada & 6 & 2 & 12 & 12 \\
\hline 4 & Health Centers Tanah Tinggi & 6 & 2 & 11 & 22 \\
\hline 5 & Health Centers H.Hasan & 6 & 1 & 6 & 9 \\
\hline 6 & Health Centers Binjai Estate & 6 & 4 & 11 & 10 \\
\hline 7 & Health Centers Jati Makmur & 2 & 1 & 4 & 7 \\
\hline 8 & Health Centers Bandar Sinembah & 2 & 1 & 4 & 10 \\
\hline 9 & Health Centers Pembantu Mencirim & 2 & - & 5 & 5 \\
\hline 10 & Health Centers Pembantu Nangka & 1 & 1 & 6 & 8 \\
\hline 11 & Health Centers Pembantu Jati Karya & 2 & 1 & 4 & 8 \\
\hline 12 & Health Centers Pembantu Tanah Seribu & 1 & 1 & 7 & 10 \\
\hline 13 & Health Centers Limau Mungkur & - & 1 & 3 & 5 \\
\hline 14 & Health Centers Limau Sundai & 1 & - & 2 & 4 \\
\hline 15 & Health Centers Pujidadi & 2 & - & 2 & 5 \\
\hline 16 & Health Centers Pembantu Tunggurono & 2 & 1 & 6 & 6 \\
\hline 17 & Health Centers Pembantu S.Muliorejo & 2 & 1 & 6 & 11 \\
\hline 18 & Health Centers Sumber Karya & 1 & 1 & 4 & 7 \\
\hline 19 & Health Centers Pembantu C. Turi & 1 & 1 & 6 & 11 \\
\hline 20 & Health Centers Pembantu Jati Utomo & 2 & 1 & 7 & 9 \\
\hline 21 & Health Centers Pembantu Tanah Merah & 1 & - & 2 & 4 \\
\hline 22 & Health Centers Pembantu Suka Ramai & 1 & 1 & 2 & 6 \\
\hline 23 & Health Centers Berngam & 2 & 1 & 6 & 5 \\
\hline 24 & Health Centers Marcapada & 1 & 1 & 4 & 9 \\
\hline 25 & Health Centers Suka Maju & 1 & 1 & 3 & 6 \\
\hline 26 & Health Centers Pembantu Dataran Tinggi & 1 & - & 9 & 6 \\
\hline \multicolumn{2}{|r|}{ Total } & 63 & 29 & 150 & 222 \\
\hline
\end{tabular}

Source : BPS Kota Binjai, 2019

The realization of the Special Allocation Fund, which is sourced from the funds of the state Budget from 2005 until 2019 relatively experienced significant 
fluctuations. Similarly, the realization of shopping at the Department of Health of the City of Binjai 2005 until 2019 fluctuated every year.

\section{The Influence Of The Shopping Area In The Field Of Education On The Human Development Index In The City Of Binjai}

Based on the results of the multiple linear regression test obtained value of the coefficient of regression of $-3,649 \mathrm{E} 12$ with a significance level of 0,369 . The significance value is greater than 0.05 ,. The significance value is greater than 0.05 and the coefficient of regression marked negative, then the partial variable Shopping Region in the Field of Education and no significant negative effect on the dependent variable Human Development Index. Thus the second hypothesis was rejected.

Along with the increasing public awareness of the importance of education, especially basic education 9 years, in the City of Binjai has a lot of standing schools ranging from Kindergarten, Elementary School, junior high School and Upper Secondary School. Similarly, the teachers also increased in terms of both quantity and quality.

The results of this study contradict with the study Muliza (2017) which states that the variable of government expenditure in the education sector has no significant effect on the human development index in the Province of Aceh, this happens because the district/city government is still more dominant allocate its spending on the type of spending that is not directly influence on the Human Development Index.

Research Umihani (2004) on the Influence of Per Capita Income And Expenditure of the Government Social sector To the Human Development Indicators: a Case Study of District/City in Central Java Province, which concluded that the government Expenditure for education and health have a more powerful influence than income per capita. In the field of education, government spending for the program, college and school education program is more effective than school education program.

Based on the results of research Marhaeni (2011) for Analysis of the Effect of Spending On Education And Health Of the Government And the Household, as well As Micro-Credit, Small, and Medium Against the Gender Development Index In the District/City In East Java Province, is known to influence government spending in education and health to the IPG is significant and the direction of the coefficient is positive, but the influence of government spending was the smallest compared with the household expenses and credit micro, small, and medium enterprises to the IPG.

Table 3 the Number of Schools From Kindergarten through high School in the City of Binjai 2018

\begin{tabular}{|l|l|l|}
\hline School Level & Country & Private \\
\hline Kindergarten & 1 & 69 \\
\hline Elementary School & 122 & 41 \\
\hline Junior High School & 15 & 35 \\
\hline Upper Secondary School & 7 & 21 \\
\hline \multicolumn{2}{|r}{ Source: Bps Kota Binjai, 2019 }
\end{tabular}

In 2018, The City Of Binjai Have As Many As 70 School-Kindergarten, Which Consists Of 1 Kindergarten And 69 Private Kindergarten, 163 Elementary School, Which Consists Of 122 Elementary And 41 Private Elementary Schools, 50 Middle School, Consisting Of 15 Junior High School And 35 Private Junior High Schools, 28 High Schools, Which Consists Of 7 Sma And 21 Private High School, 23 Vocational High School, Which Consists Of 2 Country SMK And 21 Private SMK

The Successful Development Of A Region Is Determined By The Quality Of Human Resources. Education Is One Way To Improve The Quality Of Human Resources. Therefore Improving The Quality Of Education Should Continue To Be Pursued, Starting With The Open Opportunity To The Residents To Education, To Increase The Quality And Quantity Of Educational Facilities And Infrastructure. To Find Out How Many Residents Who Use The Facilities Of Education Can Be Seen From The 
Percentage Of The Population According To The Participation Of The School.

To See The Participation Of Schools In A Region Commonly Known Some Of The Indicators To Find Out, One Of Them With A Look Gross Enrollment Rate (Ger), Which Is A Comparison Between Students At A Certain Level Of Education With Pendududuk School Age And Expressed In Percentage. The Higher The Value The Apk Means The More School-Age Children Who Attend School In A Certain Level Of Education

\section{The Influence Of The Shopping Area In The Field Of Population On The Human Development Index In The City Of Binjai}

Based on the results of the multiple linear regression test obtained value of the coefficient of regression of 9,509E10, with a significance level of 0.007 . The significance value smaller than 0.05 , then the partial variable Shopping Area in the Field of Population and significant positive effect on variables Human Development Index. Thus the third hypothesis is accepted.

Research Umiyati (2017) stated that the capital expenditure in the field of public services and significant positive effect on Human Development Index. Poverty and a significant negative effect on the Human Development Index. Economic growth has no significant effect on Human Development Index Of test Chow Test and Hausman concluded that the method of estimation of the appropriate parameters in the data of this research is to use the Fixed Effect Model.

Research conducted Widodo, Waridin, \& Kodoatie (2011) show that the allocation of government expenditure of the public sector does not directly affect the Human Development Index or poverty, but together (simultaneously) the expenditure of the public sector and the Human Development Index can affect poverty. Human Development Index also plays a role as an intervening variable, in relation to the relationship between expenditure on education and health sector and the alleviation of poverty. So give the conclusion that the expenditure of the government sector education and health will be able to affect the kemiskinaan if such expenditure is made in order to improve the quality of human development.

\section{The Influence Of Per Capita Income On The Human Development Index In The City Of Binjai}

Based on the results of the multiple linear regression test obtained the value of the regression coefficient of 7,640 E, with a significance level of 0.000 . The significance value smaller than 0.05 , then the partial variable Income Per Capita has positive and significant effect on the variable of Human Development Index. Thus the third hypothesis is accepted.

The results of this study are supported by research Umihani (2004) on the Influence of Per Capita Income And Expenditure of the Government Social sector To the Human Development Indicators: a Case Study of District/City in Central Java Province, which concluded that Per Capita Income has a positive influence and significant impact on Human Development Indicators.

Research Mahulauw (2016) about the Effect of Spending on Health And Education as well As Infrastructure On Human Development Index In the Province of Maluku shows that income per capita as an intervening variable has no significant effect on the improvement of Human Development Index. This result is not in accordance with the theory and the hypothesis that the suspect that the variable income per capita has a significant influence on the variable increase in the Human Development Index. Cases in the Province of Maluku is happening because of the increased purchasing power of the population of Maluku not always be distributed because there are still limitations of accessibility to the consumption and resources. The limitations of accessibility narrow down the choices society is not only health and education, but also the choices of 
the other so that the quality of the construction of the human is not necessarily significant.

\section{CONCLUSIONS AND \\ RECOMMENDATIONS CONCLUSIONS}

Based on the explanation and analysis conducted in the previous chapter, the conclusions that can be drawn in this research, among others:

1. Shopping Areas In the Field of Health, and a significant negative effect on Human Development Index.

2. Shopping Areas In the Field of Education, and no significant negative effect on Human Development Index.

3. Shopping Areas In the Field of Population, and significant positive effect on Human Development Index.

4. Income Per Capita has positive and significant effect on Human Development Index.

5. Shopping Areas in the Field of Health, Expenditure On Education, Expenditure In the Field of Population, Income Per Capita is able to influence the Human Development Index in the City of Binjai.

\section{RECOMMENDATIONS}

Suggestions of researchers from the research that has been done is as follows:

1. To the local government as the holder of the policy and the users of the local budget, in the budgeting process should pay more attention to the factors that have a direct influence in the fulfillment of basic needs for the people in the City Binjai, which is closely related to the Human Development Index in the City of Binjai, namely Health, education, population, and improvement of the economy of the community.

2. Local governments are expected to able and fair in distributing development in the territory of the City of Binjai so can be perceived as a direct benefit.

3. Need to be evaluated for the use of the budget for this has been implemented with mengikitsertakan academics that can give your suggestions and feedback as well as the steps that can be run in order to improve the quality of human resources in the City of Binjai.

\section{Acknowledgement: None}

\section{Conflict of Interest: None}

\section{Source of Funding: None}

\section{REFERENCES}

1. Amilda, Teni. 2014. Pengaruh Belanja Daerah di Bidang Pendidikan dan Kesehatan terhadap Komponen Indeks Pembangunan Manusia di Provinsi Bengkulu Tahun 2007-2012. Tesis. Jakarta: Universitas Indonesia.

2. Binjai Dalam Angka, 2013-2019. Badan Pusat Statistik Kota Binjai.

3. Cahyadi, Putu Eka. 2005. Pelacakan FaktorFaktor yang Mempengaruhi Indeks Pembangunan Manusia (Studi Kasus Kab/Kota di Provinsi Bali). Tesis. Jakarta: Universitas Indonesia.

4. Djuardi, Dian Komarsyah.2008. Kepuasan Masyarakat Dalam Layanan SosialEkonomi Pemerintah Kabupaten Lampung Timur.Jurnal Ilmiah Administrasi Publik dan Pembangunan, Vol.2, No.5, JuliDesember 2008.ADMINISTRATIO ISSN : 1410-8429.

5. Dwiyanto, Agus, dkk., 2003, Reformasi Tata Pemerintahan dan Otonomi Daerah, Pusat Studi Kependudukan dan Kebijakan Universitas Gadjah Mada, Yogyakarta.

6. Dwiyanto, Agus, dkk., 2005, Mewujudkan Good Governance Melalui Pelayanan Publik, Gadjah Mada Univerity, Yogyakarta.

7. Erlina.2011. Metodologi PenelitianBisnis. Medan:Usu Press.

8. Ghozali, Imam. 2012. Aplikasi Analisis Multivatiate Dengan Program IBM SPSS 20. Edisi 6. Semarang : Badan Penerbit Universitas Diponegoro.

9. Gio, P. U., \& Caraka, R. E. (2018, June 28). Pedoman Dasar Mengolah Data Dengan Program Aplikasi Statistika Statcal. https://doi.org/10.31227/osf.io/796th

10. Heriyanto, Dwi.2015. Analisis FaktorFaktor Yang Mempengaruhi Indek Pembangunan Manusia (Human 
Development Index) Kabupaten/Kota Di Provinsi Kalimantan Barat Tahun 20062010.Thesis.Universitas Tanjung Pura. Kalimantan Barat.

11. Khitam, Muhammad Chusnul. 2014. Pelayananan Publik Di Daerah Otonom Baru (Studi Pelayanan Bidang Pendidikan dan Kesehatan). J u r n a 1 E K B I S / V o 1. X I / N o. 2 / e d i s i J u 1 i 201 4. Fakultas Ekonomi Universitas Islam Lamongan.

12. Kotler, Philip. 2003. Manajemen Pemasaran, Edisi Millennium, Buku Satu, Jakarta: Penerbit Salemba Empat.

13. Laporan Keuangan Pemerintah Daerah (LKPD) Kota Binjai Tahun 2013-2019.

14. Lubis, Ade Fatma.2012. Metode Penelitian Akuntansi dan Format Penulisan Tesis.Medan : USU Press.

15. Mahulauw, Abdul Kadir. 2016. Pengaruh Pengeluaran Kesehatan Dan Pendidikan Serta Infrastruktur Terhadap Indeks Pembangunan Manusia Di Provinsi Maluku. Tesis. Universitas Brawijaya. Jurnal Ekonomi Pembangunan Vol.14, No.02 Desember 2016.

16. Mardiasmo, 2002, Akuntansi Sektor Publik, Ed.II, Andi Offset, Yogyakarta.

17. _ 2004, Akuntansi Sektor Publik. Penerbit Andi Offset, Yogyakarta.

18. , 2006. Perwujudan Transparansi

dan Akuntabilitas Publik Melalui Akuntansi Sektor Publik : Suatu Sarana Good Governance. Jurnal Akuntansi Pemerintah Vol. 2, No. 1, Mei 2006.

19. Marhaeni, Dwi. 2011. Analisis Pengaruh Pengeluaran Di Bidang Pendidikan Dan Kesehatan Dari Pemerintah Dan Rumah Tangga, Serta Kredit Mikro, Kecil, Dan Menengah Terhadap Indeks Pembangunan Gender Di Kabupaten/Kota Di Provinsi Jawa Timur. Tesis. Universitas Indonesia.

20. Muliza.2017. Analisis Pengaruh Belanja Pendidikan, Belanja Kesehatan, Tingkat Kemiskinan Dan PDRB Terhadap Human
Development Index Di Provinsi Aceh. Universitas Syiah Kuala, Banda Aceh.

21. Pratolo, Suryo. 2010. Peran Good Government Governance Untuk Mewujudkan Kinerja Pemerintah Daerah dan Kepuasan Masyarakat di Era Otonomi Daerah Dalam Menghadapi Tantangan Global (Studi pada pemerintah kabupaten dan kota di Daerah Istimewa Yogyakarta.Jurnal yang dipresentasikan pada Simposium Riset Ekonomi IV, di Surabaya Tahun 2010.

22. Rahmati, Novi Eka.2013. Pengaruh Akuntabilitas dan Transparansi Pemerintah Daerah Terhadap Kepuasan dan Kepercayaan Masyarakat. Tesis.Yogyakarta: Universitas Gajah Mada.

23. Rendi JA. Sudarto, R.J. Poluan dan Edi D. Takumansang.2014. Analisis Tingkat Kepuasan Masyarakat terhadap Kinerja Pelayanan Publik PT. Air Manado.Jurnal Sabua Vol.6, No.3:307-319 November 2014.

24. S Sitompul, RN Ichsan, L Nasution.2021. The Influence of Exchange Rate, Inflation, For the Results of the Development Assets of Islamic Banks. Journal of Economics, Finance and Management Studies. Vol. 4, Issue 3 March 2021: 138-148.

25. Sasana, Hadi.2010. Kepuasan Masyarakat Terhadap Pelayanan Kelurahan Setelah Pemekaran di Tangeran Selatan.Jurnal Aset. Vol 12 nomor 2. September 2010. Hal 95105.

26. Sekretariat Daerah Kota Malang. 2015. Laporan Survei Kepuasan Masyarakat Pemerintah Kota Malang - Tahun 2015.

How to cite this article: Barus EN, HB. Tarmizi, Rahmanta. Analysis of factors affecting human development index in the city of Binjai. International Journal of Research and Review. 2021; 8(4): 161-170. DOI: https://doi.org/ 10.52403/ijrr.20210422 